\title{
Spatial analysis of dumpsites volumes from rural territory. Case study: Neamţ County, Romania
}

\author{
Florin - Constantin MIHAI ${ }^{1, *}$, Andreea LĂMĂȘANU ${ }^{1}$ \\ ${ }^{1}$ Department of Geography, "Alexandru loan Cuza" University, Carol I Avenue, No. 20 A, RO-700505, Iași, Romania \\ * Corresponding author, mihai.florin86@yahoo.com
}

Received on <01-02-2012>, reviewed on <27-06-2012>, accepted on <26-03-2013>

\begin{abstract}
Open dumps was the main option of the local communities in household waste management, this practice being banned after July 16, 2009. The paper examines the correlation between dumpsites volumes, population density and local geographical conditions in the context that in most rural administrative-territorial units of the county there were no facilities for waste collection. The geographical distribution of dumpsites volumes reflects the disparities between different areas of the county and on the other hand, it highlights the spaces exposed to pollution. Also, the comparative analysis between 2004 (preaccession) and 2009 (post-accession) reflects a rudimentary waste management system in this period which favored the waste dumping. This paper analyses the issues of rural waste management and its environmental implications at local scale. Such approaches are necessary for a proper analysis of EU environmental policies implementation at regional and local level.
\end{abstract}

Keywords: dumpsites, spatial analysis, geographical conditions, rural areas, Neamț county, Romania
Rezumat. Analiza spațială a volumelor depozitelor de deseuri din teritoriul rural. Studiu de caz: Județul Neamț, România

Depozitele de deșeuri neamenajate au reprezentat principala opțiune a comunităților locale privind gestionarea deşeurilor menajere, această practică fiind interzisă după data de 16 iulie 2009. Lucrarea examinează corelația dintre volumele acestor depozite, densitatea populației și condițiile geografice locale în contextul în care în majoritatea unităților administrativ-teritoriale rurale din județ nu existau facilități pentru colectarea deşeurilor. Distribuția geografică a volumelor acestor amplasamente reflectă disparități majore între spații ale județului şi subliniază perimetrele expuse poluării. Totodată, analiza comparativă între anii 2004 (pre-aderare) şi 2009 (postaderare) reflectă o gestionare neconformă a deșeurilor din acest interval de timp, favorizând eliminarea necontrolată a deșeurilor. Lucrarea analizează problemele gestionării deșeurilor menajere din teritoriul rural și implicațiile asupra stării mediului la scară locală. Astfel de abordări sunt necesare pentru o analiză adecvată a implementării politicilor de mediu ale UE la nivel regional și local.

Cuvinte-cheie: depozite de deșeuri, analiză spațială, condiții geografice, zone rurale, județul Neamț, România

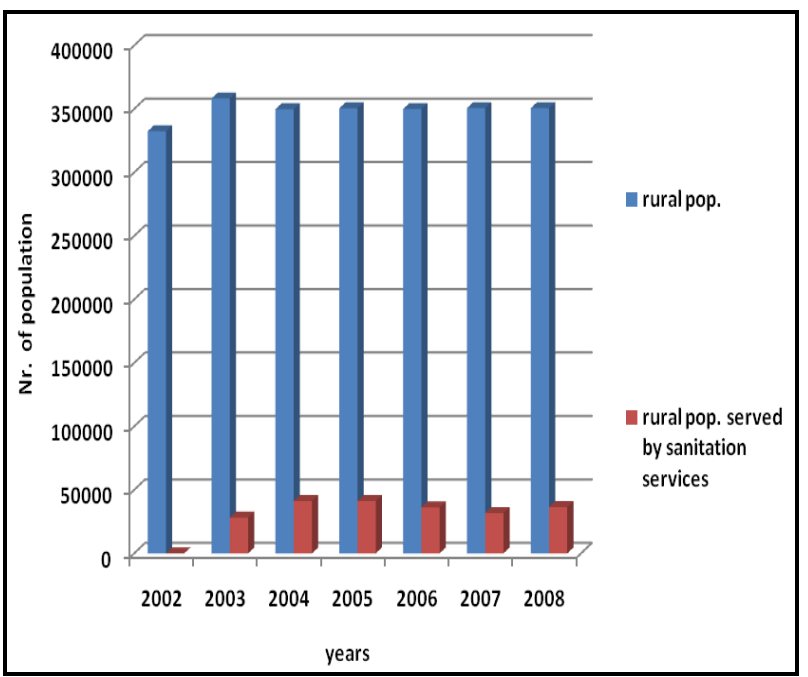

Fig.1: Population served by waste collection services (Data source: APM Neamt, 2010)

This fact favored the illegal dumping of household waste generated and uncollected (Lămășanu and Mihai, 2012). Physical-geographical transition of Suceava, Neamț and Bacău counties is 
reflected in disparities concerning the distribution of rural dumpsites within the same county, while in eastern counties (Botoșani, Iași and Vaslui) this distribution is more uniform due to a more homogeneous landscape (Mihai et al., 2012b). This paper aims to analyses if the pattern of distribution for dumpsites volumes within Neamt County is the same. Alongside socio-economic and demographic features of communes which reflect the amounts of generated waste, local landscape influence how the waste is disposed of by local communities.

Therefore, main parameters of a dumpsite (area, volume) also depend on the local landscape in the proximity of settlements. Thus, this approach cannot be ignored particularly in rural waste management studies. In time, the extension and improvement of waste facilities from rural areas will minimize this role.

\section{Methods}

Often rural dumpsites are small ( $<1 \mathrm{ha}$ ) having a short life (particularly in the proximity of rivers) with a various distribution within county, being difficult to follow in the field. In this context, a statistical distribution of dumpsites volumes at local administrative units is more proper using thematic cartography. Firstly, a database regarding the dumpsites volumes (m3) for 2004 (pre-accession) and 2009 (post-accession) was achieved, calculating the total sum for every commune which reported such sites on their territory. Data are provided by National Environment Guard, County Commissariat, being more reliable for 2009 due to the implementation of EU acquis on rural dumpsites, consisting in the inventory, closure and rehabilitation of all these sites. The full procedure for Neamt county was analyzed by Apostol and Mihai (2012). Mapping these data was performed using range colours for rural population density (relative values-hab. $/ \mathrm{km}^{2}$ ) and correlated with dumpsites volumes (absolute values- $\mathrm{m} 3$ ) using proportional circles. Also, the Jenks discretization method was used for population density (2005) to outline the disparities between communes concerning demographic pressure on the local environment. Field observations during 2009-2011 (which covered more than half of the county from rural territory) comparative analysis (2004 vs. 2009) and geographical distribution of settlements across county contribute for a proper interpretation of results. The paper proposes a conceptual scheme (in situ - ex situ) for impact assessment of a dumpsite on local environment.

\section{Discussion}

The EU policy on waste management focuses on waste hierarchy concept which promotes to reduce, reuse, and recycle (3R), treatment, and incineration with energy recovery and in the last case land filling.
Several technological systems are used by EU members (Pires et al., 2011) and implementation of this policy across UE-27 is difficult due to major disparities reflected in municipal waste management systems (Mihai and Apostol, 2012a; Mengozzi,A.,2010 ). In order to mitigate these disparities, European directives on waste management are transposed into national laws and each member develops national, regional and local waste management plans according to these regulations. Romania, as new member, has a transition period for implementing the EU targets. Thus, the deadline for closure of rural dumpsites was 16th of July, 2009. Following this date, local authorities are obliged to provide waste collection on their territory. Therefore, during 20042009 period, the waste dumping on inappropriate sites was a common practice because of poor waste management services, dumpsites volumes ranging between communes. In the best cases, local authorities have chosen some sites where the waste could be disposed. Sanitation services were not well organized and waste collection did not occur regularly. The paper aims to offer a proper interpretation of their distribution taking into account the population density and local landscape. Physicalgeographical transition from west to east leads to the uneven distribution of human settlements as well of population density (Fig. 2 and Fig. 3).

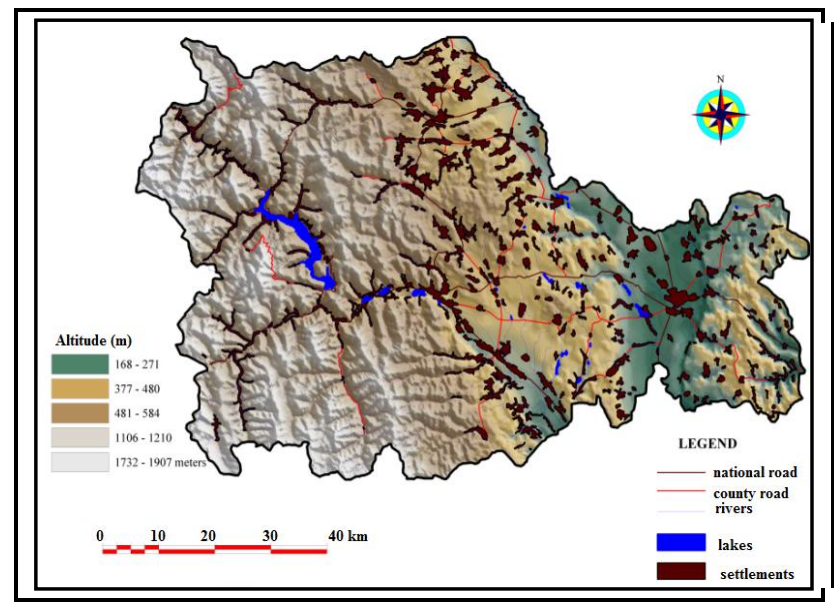

Fig. 2 Distribution of human settlements

The highest concentration of human settlements (107.5 -339.8 hab./km2) is to be found on the terraces of the Siret and Moldova rivers, in the Cracău - Bistrița Subcarpathian depression (the communes downstream of Piatra Neamt town) and lower in the Moldavian Plateau or Carpathian region ( $<55$ hab./km2).

Commonly, those well-populated areas correspond to the largest volumes of dumpsites (except the Subcarpathian sector of the Bistrița valley). Both years (Fig.3) have the same pattern in spatial distribution of dumpsites volumes, increasing from west (mountain region) to east (Subcarpathian region, corridor valley and plateau) as well as population density. 

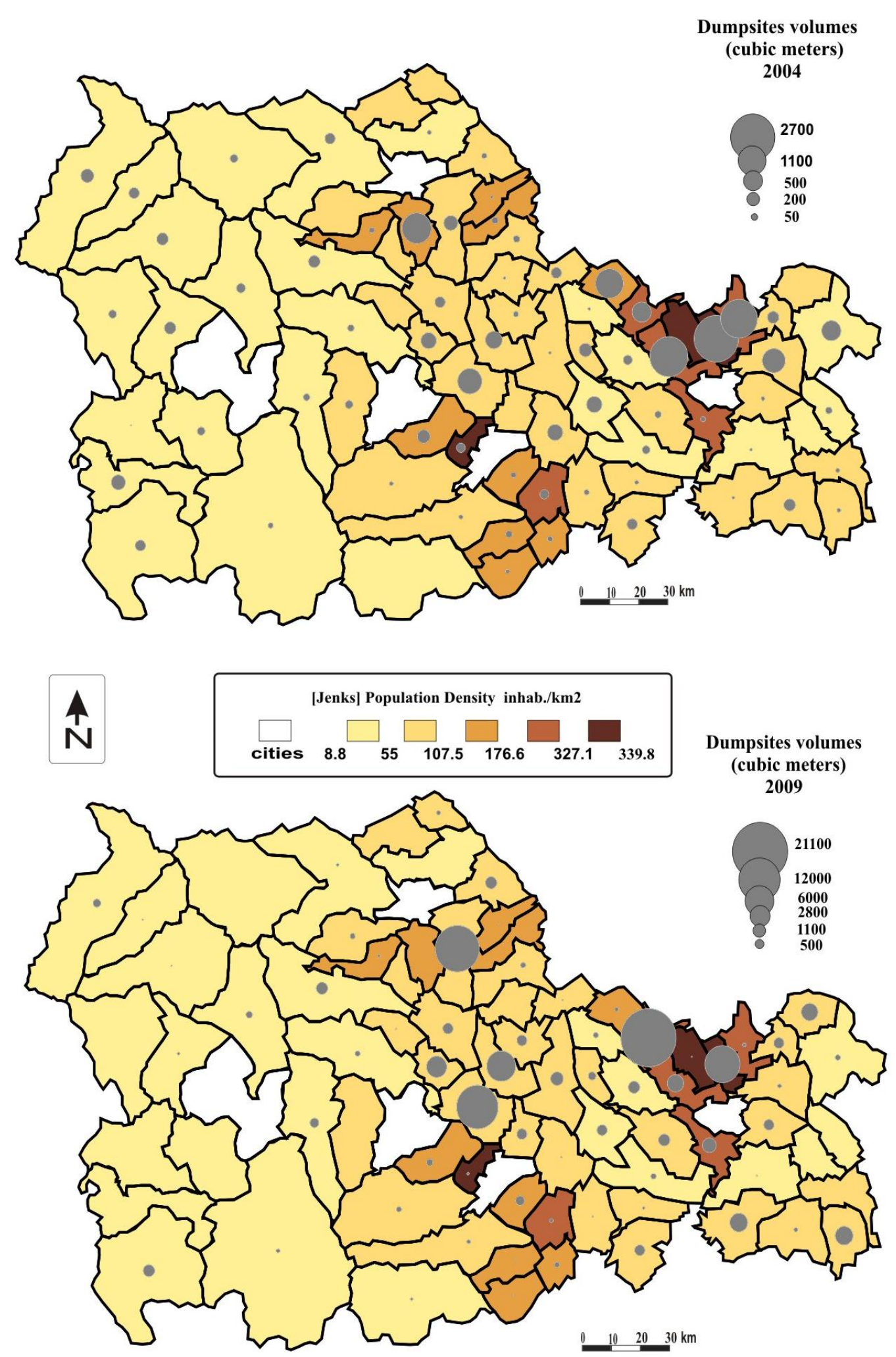

Made with * http://philcarto.free.fr

Data source : National Environment Guard, County Commissariat

Fig. 3 Geographical distribution of dumpsites volumes (2004 vs. 2009) 
In most communes, the dumpsites volumes from 2009 are significant larger than in 2004; moreover not all communes reported such sites on their territory even if they did not provide waste collection services. Field observations revealed the fact that such communes are facing illegal dumping. Dumpsites volumes in 2004, were frequently less than $100 \mathrm{~m} 3$, only 5 communes had more than 1000 $\mathrm{m} 3$, the maximum value being $2700 \mathrm{~m} 3$ for Tămășeni. On the other hand, in 2009 the largest volumes were registered in Gherăești commune, $21100 \mathrm{~m} 3$, followed by Petricani (13280 m3), Girov $(12000 \mathrm{~m} 3)$ and others 8 communes with more 1000 $\mathrm{m} 3$. In mountain region, localities are placed linearly along the main valleys (the Bistrița and the Bicaz rivers) with numerous branches on tributary streams. The lack of waste collection services from this part of the county led to uncontrolled disposal of mixed waste (household waste, agricultural waste, sawdust) in rivers or on their river banks which are often filled by floods polluting the downstream lakes: Izvoru Muntelui, Pângărați, Bâtca Doamnei). These floods explain the low dumpsites volumes $(<500 \mathrm{~m} 3)$ from the western half of the county comparing to other regions. The network of settlements is extended with higher population densities in Sub-Carpathian, plateau and corridor valley regions (>107.5 hab./km2). Dumpsites volumes are larger (or it should be ) in these areas than in the mountain sector because the waste disposal is done on several years in open dumps located ordinarily on alluvial plains, fluvial terraces, old geological sites, roadsides, forest areas or degraded lands. The development of compact human settlements on the large terraces of the Moldova and the Siret rivers allows a high concentration of population which explains the larger dumpsites volumes for these communes (e.g. Gherăești, Botești, Doljeşti etc). The lifespan of these sites is also greater than in the mountain or Subcarpathian regions, being less exposed to the floods. Therefore, well-populated communes ( $>100$ hab./km2) located in the Subcarpathian depressions (Neamţ, Cracău-Bistrița) had low dumpsites volumes ( $<500 \mathrm{~m} 3)$ because of waste disposed on floodplains (Cracău, Bistriţa Ozana sector) or on the banks of tributaries, being "collected" by floods as well in mountain regions. The rivers in the proximity of human settlements from the mountain or Subcarpathians regions are most vulnerable to waste dumping because of the poor waste collection services. Also, in plateau region, local population dispose the household waste on streams (summer dry riverbeds), but the impact of floods on these sites is more limited. In some cases, the large number of component localities (e.g. Bârgăoani commune-which include 11 dispersed small villages) increase the number and/or occupied areas (m2) of open dumps, but with low volumes. Furthermore, the low population density and poverty of communes from the center and the south-eastern part of county reflect the low dumpsites volumes, usually $<500 \mathrm{~m} 3$. Toxic potential of a landfill varies depending on surface (ha), volumes/amounts of land filled waste (tons) and waste composition (the presence of hazardous waste). The geographical context of the dumpsite leading to various systemic interactions between the site and the surrounding, generating different types of pollution (air, water, soil, ecosystem and settlements pollution) and damaging the local landscape must also be taken into account (see Fig.5). These dumpsites from rural areas and those from small towns which covered less than 10,000 $\mathrm{m} 2$, and had a volume below $20,000 \mathrm{~m}^{3}$ ) were closed, compacted and covered by soil, (Fig.4) or the amounts of waste disposed were transported to the urban landfills in the proximity. Unfortunately, there are no studies concerning the waste composition at local scale, only estimations made by waste operators from urban areas.

Biodegradable waste (which has a ratio of over $50 \%$ of household waste in Neamt County) is used by the local people as a source of food for livestock or it is biodegraded by traditional composting (mixed with manure) and reused to enrich soil. Recyclable waste (paper, cardboard, plastic, metal, wood), inert waste (glass, construction and demolition waste) and others (tires, WEEE, textiles) are disposed in such dumpsites representing less than half of the amounts of waste generated, thus reflecting the low dumpsites volumes from rural areas.

On the other hand, these dumpsites also contain not only household waste, but agricultural waste or even hazardous waste may be found as well. Also, sawdust was dumped widespread in mountain region but now a plant from Tașca commune uses this fraction as fuel. Following the closure of rural dumpsites, waste collected from communes should be transported to non-compliant landfills (Roman or Târgu-Neamț).

Due to this regulation, waste collection services covered more communes in 2010/2009 compared to 2004 but the rate of collection at county level is still low, $35.13 \%$ for 2010 . The project of integrated solid waste management system for Neamt County approved and co-financed through Environmental Sectoral Operational Programme (2007-2013) stipulates the construction of three transfer stations equipped for sorting, separating and collecting of household waste. These facilities will be located in Târgu Neamt (17.000 t/yr), Tașca (9000 t/yr), Cordun (commune near Roman town, $45.000 \mathrm{t} / \mathrm{yr}$ ) and will receive the waste collected from rural localities in their proximity. The waste that cannot be recovered will be disposed in the regional sanitary landfill located in Girov commune as shown in Fig.6. 


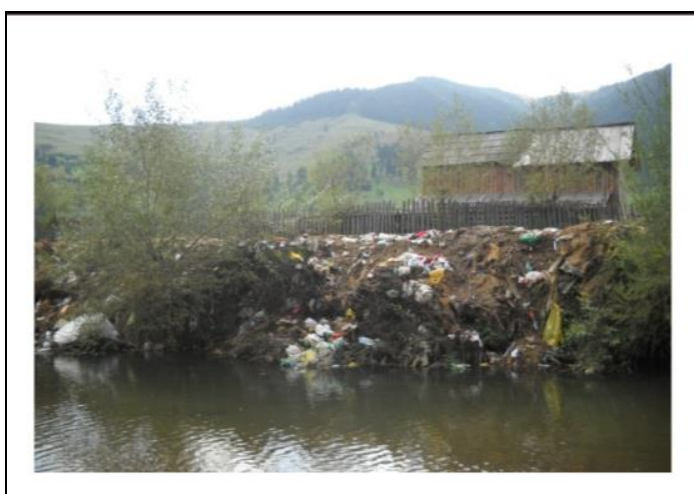

Rural dumpsite on Bistrița river bank,Sept.2009 Poiana Teiului commune

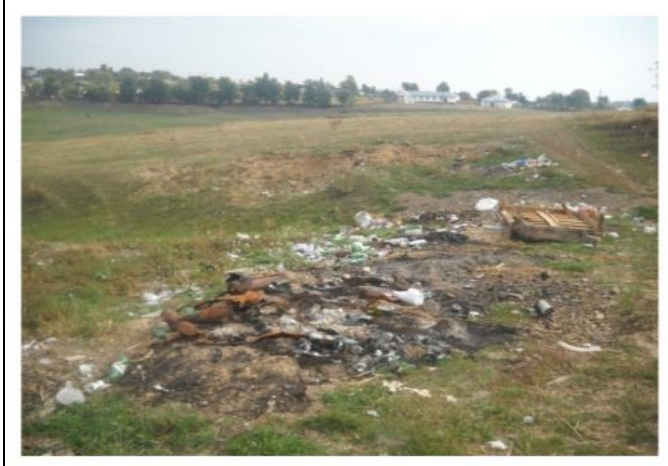

Dumpsite, Moldavian Plateau, Boghicea commune,Sept.2009

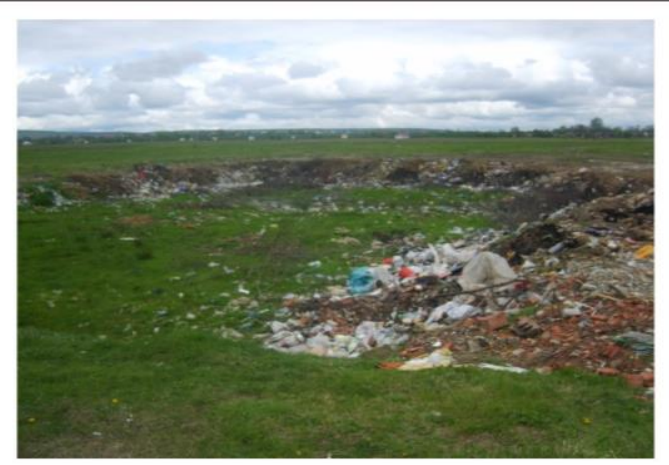

Open dump on Bistrița floodplain, Cut village,Dumbrava Roșie commune

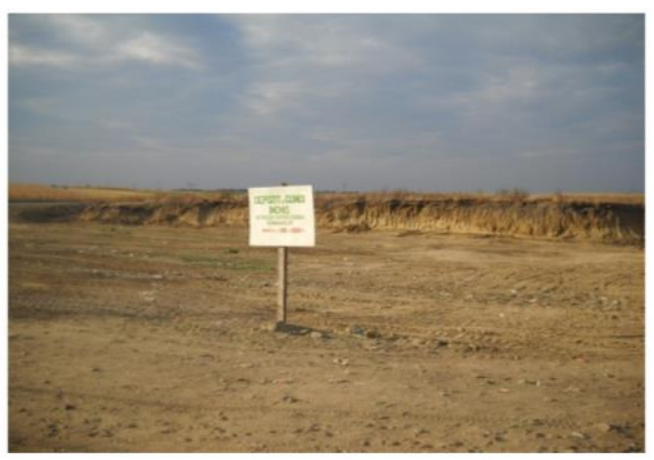

Rural dumpsite - compacted and soil covered, Gherăești commune,Sept.2009

\section{Fig.4 Examples of rural dumpsites - field observations}

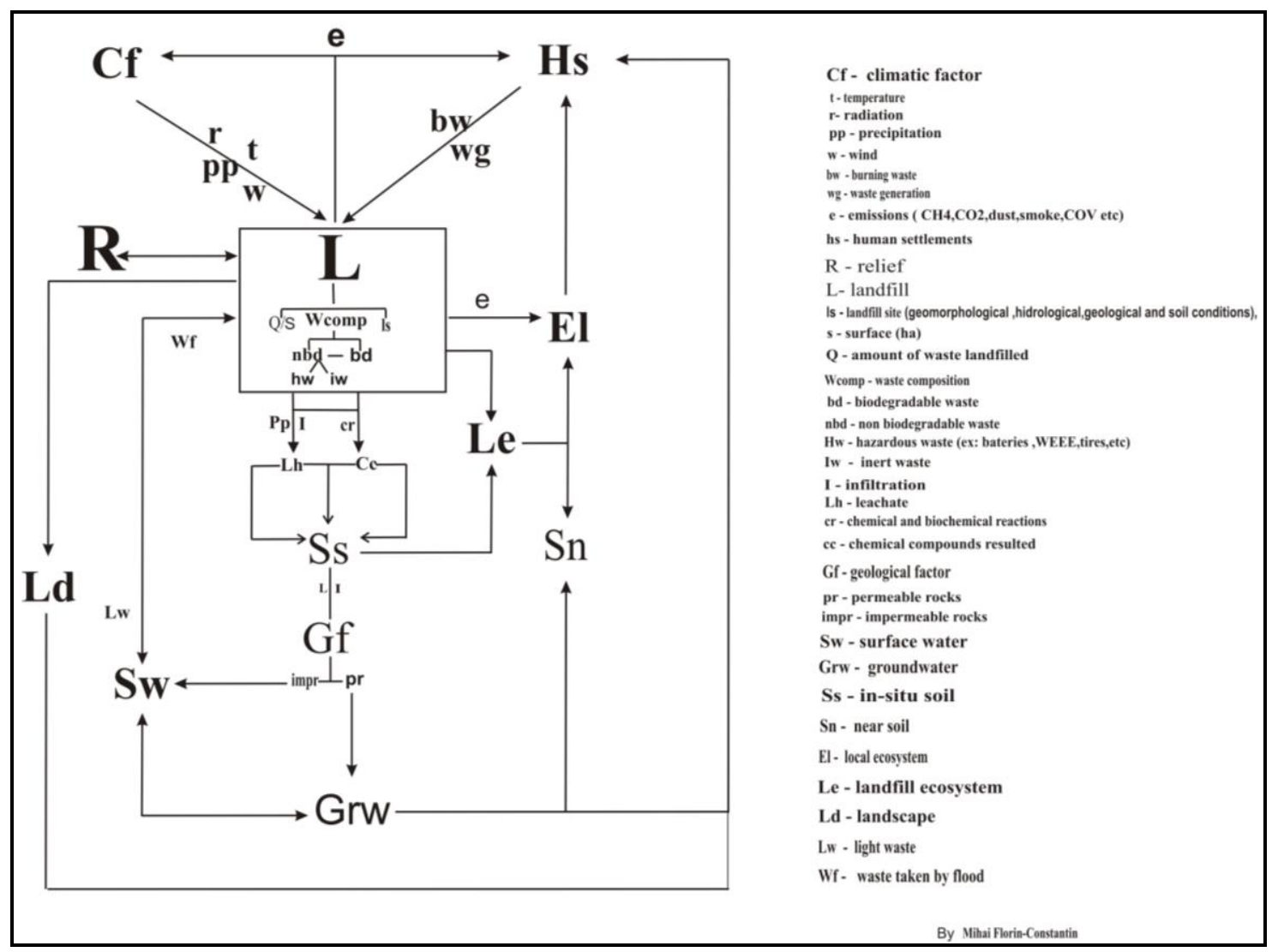


Fig.5: Geosystemic interactions between a landfill site and the surrounding area

Waste collection services from rural ares after the closure of rural dumpsites

( July 2009 - April 2010)

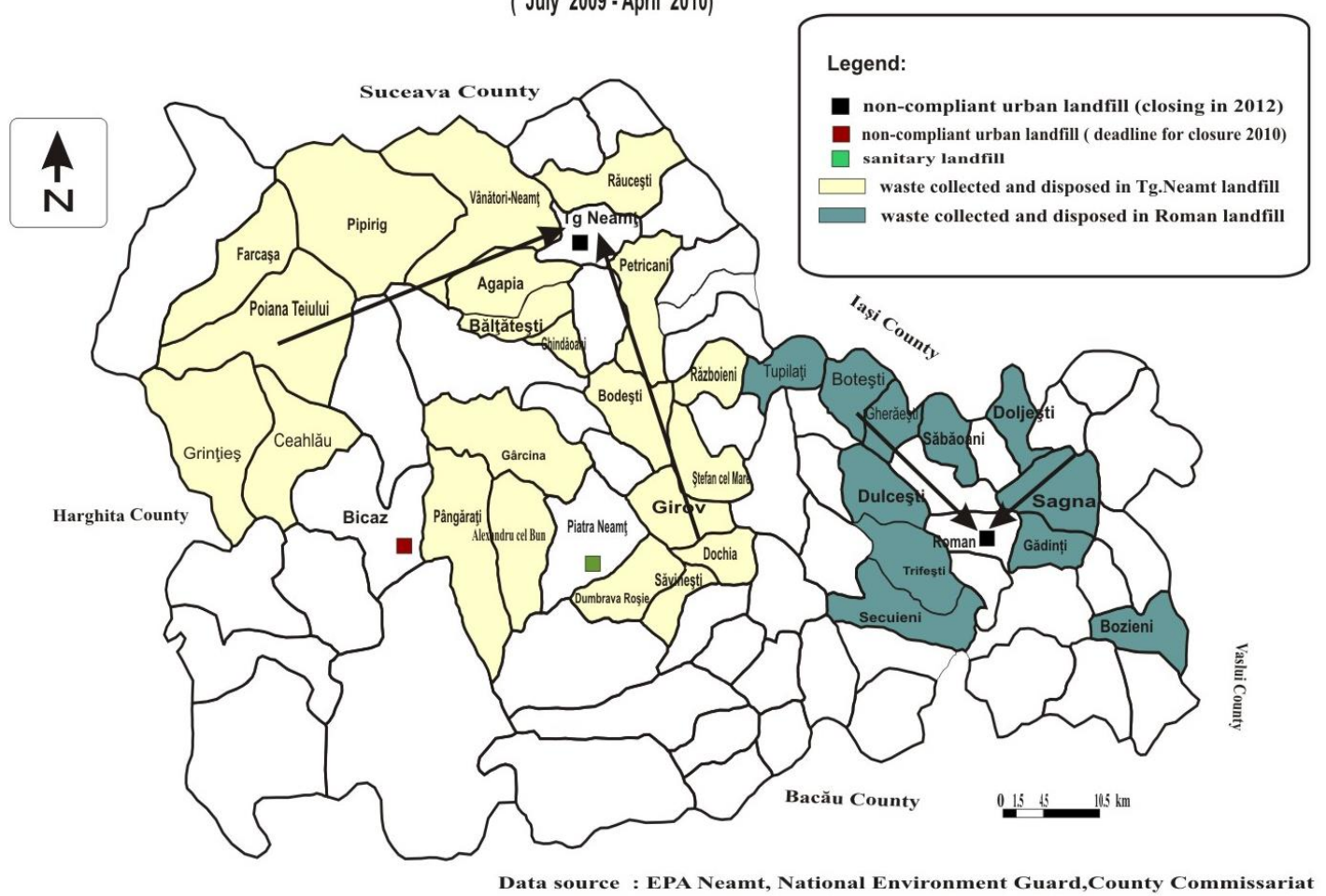

The future integrated solid waste management system

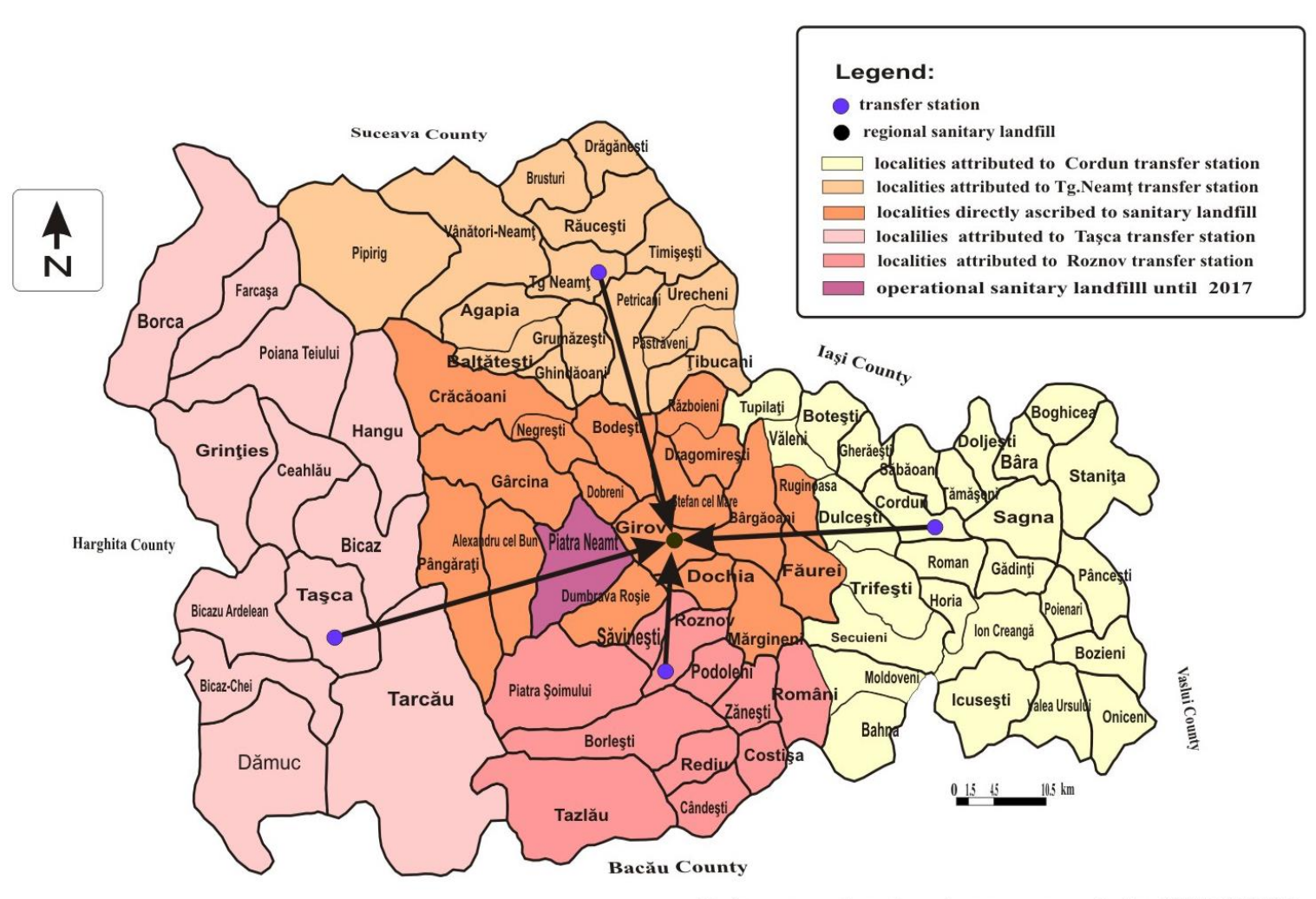

Data source : Local waste management plan,2008 (PJGD)

Fig.6 Present and future of rural waste management system in study area 
(Mihai and Apostol, 2012b, modified)

Also, the sanitary landfill from Piatra Neamt town will be operational until 2017; following this term the waste collected will be disposed in Girov landfill. It should be noted that the sanitary landfill from Piatra Neamt supported by ISPA funds does not allow the disposal of the waste collected from rural areas.

Because of this situation, waste collected (20092010) from peri-urban communes (Dumbrava Roşie, Girov, Gârcina, Alexandru cel Bun) are transported to non-compliant landfill of Târgu Neamt town (deadline for closure - July 2012), increasing the cost of these services until the transfer stations and regional landfill will become operational (Fig.5). Mixed waste collection prevails, separate collection is rarely seen and usually only plastic fraction is collected. However, in 2011, separate collection containers were installed for plastics, paper / cardboard, biodegradable and residual waste in Piatra Şoimului and Borlești communes. These facilities were supported by PHARE CES 2005 funds, including a transfer station in Roznov town which serves the surrounding rural areas.

\section{Conclusions}

Poor solid waste management facilities during 2004 -2009 encourage the bad practices such as waste dumping on inappropriate sites. Distribution of dumpsites volumes (2010 vs. 2004) reflects the same pattern as that for population density, low volumes in western half (mountain region) which increases in the eastern half of county. This paper highlights how local landscape (in the proximity of communes) influenced the distribution of dumpsites volumes. These sites have large volumes in well-populated communes located in hilly areas or on fluvial terraces (low vulnerability to floods). This approach is proper at local scale in the context of limited access of population to waste collection services. Therefore, these factors correlated with field observations cannot be ignored in rural waste management studies. Development of waste management sector services on rural territory is emerging under the pressure of EU regulations. Also, the PHARE and ENV-SOP funds contributed to the recent improvements of waste management facilities in the study area.

\section{Acknowledgements}

Authors would like to thank National Environmental Guard, County Commissariat of Neamt for informational support.

\section{References}

Abduli, M. A., Samieifard, R. \& Jalili, G.Z.M. (2008). Rural Solid Waste Management. Int. J. Environ. Res., 2(4), 425-430

Apostol, L., Mihai, F. C. (2011). The process of closing down rural landfills Case study : Neamt county. Present Environment and Sustainable Development, 5 (2), 167- 174

Athanassiou, M., Zabaniotou, A. (2007). Technoeconomic assessment of recycling practices of municipal solid wastes in Cyprus. Journal of Cleaner Production, 16, 1474-1483

Bel, G., Mur, M. (2009). Inter-municipal cooperation, privatization and waste management costs: Evidence from rural municipalities. Waste Management, 29, 2772-2778

Chen, C. C. (2010). Spatial inequality in municipal solid waste disposal across regions in developing countries. Int. J. Environ. Sci. Tech., 7 (3), 447-456

Jolanta, M. K., Piotr, Ł. (2005). Local waste management - the case of "BESKID Company. Acta Montanistica Slovaca Ročník 10 mimoriadne číslo $1,186-189$

Kulczycka, J., Zygmunt, K. (2008). Principles of municipal waste management in Poland and selected regions of Europe. Polish Journal of Chemical Technology, 10 (4), 28-33

Lămășanu, A., Mihai, F. C., (2012), The Illegal Dumping of Waste in Forest Areas - Evidence from Rural Territory. Proceedings of the International Conference Integrated Management of Environmental Resources -,November 4-6th, 2011, Suceava, Romania, 46 - 50

Mamdouh, A. M., Gaber, A.Z. I. \& Anwaar, K. A., (2009). Evaluation of Municipal Solid Waste Management in Egyptian Rural Areas. $J$ Egypt Public Health Assoc, 84 ( 1 \& 2), 51- 71

Massarutto, A. (2007). Municipal waste management as a local utility: Options for competition in an environmentally-regulated industry. Utilities Policy , 15 , 9-19

Mengozzi, A., (2010). Waste Growth Challenges Local Democracy. The Politics of Waste between Europe and the Mediterranean: a Focus on Italy, California Italian Studies Journal, 1(1),1-21

Mihai, F.C., Apostol, L.(2012a). Disparities in municipal waste management across EU-27. A geographical approach. Present Environement and Sustainable Development, 6 (1), 169-180

Mihai, F.-C., Apostol, L. (2012b). Development of waste collection services on rural territory from Neamt County. Analele Universităti Oradea, Fascicula: Protectia Mediului, 18 (1), 370-375 
Mihai, F.C., Apostol,L., Lămășanu, A., Ghiurcă, A.A, (2012).Spatio-temporal analysis of Romania's rural population access to sanitation services in the context of EU accession, Conference Proceedings of $12^{\text {th }}$ International Multidisciplinary Scientific GeoConference,SGEM,17-23 June, 2012, Albena, Bulgaria, 5, 787-792, (DOI: $10.5593 /$ sgem2012/s20.v5106)

Mihai, F.-C., Apostol, L., Ghiurca A.A, Lămășanu A., Bănică A., (2012). Geographical distribution of rural dumpsites in North-East Region from Romania, Conference Proceedings of $12^{\text {th }}$ International Multidisciplinary Scientific GeoConference SGEM,17-23 June 2012,Albena,Bulgaria,5, 447-452, DOI: $10.5593 /$ sgem2012/s20.v5060)
Orosz, Z., Fazekas, I. (2008). Challenges of municipal waste management in Hungary. AGD Landscape \& Environment 2 (1) 78-85

Pires, A., Martinho, G., Chang, N.B. (2011). Solid waste management in European countries: A review of systems analysis techniques, Journal of Environmental Management,92, 1033-1050

*** APM Neamţ. 2010. Raport anual privind starea factorilor de mediu in județul Neamț

*** ARPM Bacău. 2006. Planul regional de gestionare a deșeurilor în regiunea $1 \mathrm{~N}-\mathrm{E}$

*** CJ Neamț.2008. Planul județean de gestionare a deșeurilor in județul Neamt 